\title{
KRIZNO UPRAVLJANJE NA OBRAMBNEM PODROČJU S POUDARKOM NA SLOVENSKI VOJSKI
}

\section{CRISIS MANAGEMENT IN THE FIELD OF DEFENCE, WITH EMPHASIS ON THE SLOVENIAN ARMED FORCES}

Povzetek Varnost danes ni ogrožena le zaradi oboroženih konfliktov, temveč predvsem in vedno pogosteje zaradi kompleksnih kriz. Učinkovit odziv nanje zahteva od nacionalnovarnostnega sistema stalno prilagajanje in pripravljenost na nepredvidljivost varnostnih razmer s prožno strukturo, razvito koordinacijo in z zmogljivostmi, sposobnimi ukrepanja na podlagi sistemskih in jasnih pravil na področju kriznega upravljanja. Prispevek osvetljuje pomen kriznega upravljanja v sodobni družbi s poudarkom na obrambnem področju, na katerem na podlagi teoretičnih in praktičnih spoznanj daje predloge, ki bi lahko bili za Slovensko vojsko kakovosten izhodiščni okvir za razpravo pri oblikovanju nujnih odgovorov na sodobne izzive kriznega upravljanja. Slovenija, njen nacionalnovarnostni sistem in vse njegove sestavine, vključno s Slovensko vojsko, si ne smejo in ne morejo dovoliti, da krizo pričakajo nepripravljeni ter brez vnaprej izoblikovanega in delujočega celovitega koncepta na področju kriznega upravljanja.

Ključne besede

Abstract

\section{Kriza, krizno upravljanje, krizno odzivanje, vaje kriznega upravljanja.}

Today, security is not threatened only because of armed conflicts, but mostly and increasingly because of the complexity of crises. An effective response to those crises requires the national security system to constantly adapt and remain ready for the unpredictable nature of the security situation. This can be achieved with a flexible structure, well-developed coordination and capabilities apt to react on the basis of clear and system rules in the field of crisis management. The article highlights the importance of crisis management in the modern society with the emphasis on the field of defence. It provides theory- and practice-based suggestions, which could serve as a quality frame of reference for a discussion in the process of preparing crucial responses to the contemporary challenges of crisis management. Slovenia, its 
national security system along with its components, including the Slovenian Armed Forces, cannot and should not presume to enter a crisis unprepared and without a pre-framed, effective and comprehensive crisis-management concept.

\section{Key words Crisis, crisis management, crisis response, crisis management exercises.}

Uvod Krize so pojav, ki danes še bolj kot v preteklosti zaznamujejo mednarodno varnostno okolje (teroristični napadi, naravne in tehnične nesreče, globalni problemi lakote, nalezljive bolezni, migracije, okoljski problemi, gospodarske krize idr.) in zahtevajo veliko družbene pozornosti, saj nanje ni nihče absolutno odporen. Razumevanje krize kot situacije, ki ogroža temeljne družbene vrednote, prinaša veliko negotovosti in dopušča relativno kratek čas za ukrepanje, zahteva od varnostnih in obrambnih instrumentov pravočasno, usklajeno in učinkovito ukrepanje, z vnaprej pripravljenimi in celostno usklajenimi mehanizmi kriznega upravljanja, vodenja in odzivanja. V tem pogledu predstavlja povezljiv in funkcionalen sistem kriznega upravljanja temeljni predpogoj uspešnega operativnega načrtovanja na področju kriznega upravljanja tako v mednarodnih integracijah kot tudi nacionalnih okvirih.

Temu dejstvu mora slediti Republika Slovenija (RS) z nujnim premislekom o posodobitvi oziroma dopolnitvi kriznega upravljanja in vodenja (KUV), ki bo temeljila na medresorski povezanosti ter prožnem odzivanju na kompleksne krize. Na ravni Vlade RS je projektna skupina ${ }^{1}$ že pripravila predlog nove strukture KUV (pri sklicevanju na to skupino bomo uporabili naziv vladna projektna skupina). $\mathrm{Na}$ vrsti so sestavine nacionalnovarnostnega sistema, torej tudi obrambni sistem ter znotraj njega Slovenska vojska (SV), da pregledajo sedanje stanje na področju kriznega upravljanja ter ga uskladijo z rešitvami vladne projektne skupine in umestijo v okolje integracij, znotraj katerih delujejo. Vprašanji, ki si ju moramo pri tem zastaviti, sta: »Ali je SV s svojimi zmogljivostmi optimalno vpeta $\mathrm{v}$ sistem kriznega upravljanja na obrambnem področju in kako učinkovito se lahko spoprime s krizo?«

Glavno raziskovalno vprašanje prispevka izhaja iz trditve, da umestitev SV v sistem kriznega upravljanja na obrambnem področju ni celovita, kar posledično zmanjšuje njeno vlogo pri delovanju in uresničevanju ciljev kriznega upravljanja in pri odzivanju na krize. Prispevek se osredotoča na model in procese kriznega upravljanja na obrambnem področju v krizi, ne glede na dejstvo, ali SV deluje v okviru zaščite, reševanja in pomoči, v okviru policije ali samostojno, doma ali na kriznih območjih, pod nacionalno ali zavezniško zastavo. Gre za proces upravljanja, vodenja in

\footnotetext{
Ministrstvo za obrambo je prevzelo vodenje enega izmed vladnih strateških projektov, in sicer P7: Sistem kriznega upravljanja in vodenja $v$ RS, sofinanciranega iz evropskega sklada za notranjo varnost. Projekt Sistem kriznega upravljanja in vodenja predvideva pripravo predloga strukture kriznega upravljanja in vodenja pri Vladi RS za odzivanje na kompleksne krize, izpopolnitev mehanizmov za njihovo upravljanje ter predlog normativnopravnih rešitev. Delni rezultati omenjenega vladnega strateškega projekta so bili predstavljeni v publikaciji z naslovom Upravljanje kompleksnih kriz v Republiki Sloveniji (Vuga Beršnak (ur.), 2016).
} 
odzivanja na krizo pred in med krizo ter po njej, ki bi moral biti izoblikovan, celovit in preizkušen ter usklajen z nacionalnim in Natovim ter EU-procesom kriznega upravljanja. Končni cilj prispevka je (1) razširiti zavedanje tako znotraj SV kot tudi širše, da je krizno upravljanje ključni dejavnik načrtovanja in odločanja v krizni situaciji na obrambnem področju, in (2) na podlagi pridobljenih spoznanj predstaviti idejni koncept kriznega upravljanja v SV na obrambnem področju.

\section{KRIZA IN KRIZNO UPRAVLJANJE}

V prispevku obravnavamo pojem kriza dovolj splošno, da lahko zajamemo njegovo uporabnost tako v nacionalnem kot tudi mednarodnem okolju. Takšno opredelitev krize navaja na primer Malešič $(2004,11-12)$, in sicer, da gre pri krizi za krizno situacijo, v kateri so ogrožene temeljne družbene vrednote, norme in strukture, v kateri je čas za odločanje omejen in ki prinaša negotovost, stres, pogosto tudi presenečenje $\mathrm{e}^{2}$.

V času intenzivne informatizacije in tehnološkega napredka, globalizacije, hibridnih groženj ipd. je treba gledati na krizo tudi kot na kompleksen družbeni pojav, z vplivom na različna področja varnosti, transnacionalnim učinkom ter akumulacijo negativnih učinkov, ki se pogosto pojavijo po umiritvi krizne situacije (okoljski problemi, kriminal, spori itn.). Celovitejši pogled na sodobno razumevanje krize, ki jo v literaturi zasledimo pod pojmom kompleksna kriza, je praviloma povezan še s povečano občutljivostjo ljudi na krize in zmanjšano sposobnostjo sistema za učinkovito odzivanje na vseh prizadetih področjih. Kompleksna kriza nastane takrat, ko se grožnja eni prvini v trenutku razširi na druge in je opredeljena opisno, največkrat z značilnostmi prepletene grožnje, učinkom domin, nelinearnim procesom, negativnimi dogodki s sinergijskim učinkom, visoko stopnjo tveganja ipd. Zato je za krizno upravljanje pomembno vedeti, ali imamo opravka s kompleksno krizo, saj je za njeno reševanje nujen celovit pristop h kriznemu upravljanju ${ }^{3}$. Tudi vladna projektna skupina poudarja pomen termina kompleksna kriza, ki ga opredeljuje kot

\footnotetext{
Opredelitev krize kot pojma najdemo na normativnem področju v nacionalnem prostoru tudi v predlogu novele Zakona o obrambi, kar je novost. Kriza je v njem opredeljena kot stanje pravne kategorije, ki nastane kot posledica dogodkov, ki ogrožajo varnost (nacionalno ali mednarodno) in lahko vodijo tudi v izredno stanje ali vojno. Za njeno obvladovanje je treba uveljaviti ustrezne ukrepe kriznega odzivanja, ob upoštevanju obveznosti, prevzetih s članstvom v mednarodnih organizacijah (EVA 2016-1911-0001). Z vidika problematike proučevanja pa je najpomembneje, da predlog zakona povsem na novo predvideva načrtovanje delovanja obrambnega sistema v kriznih razmerah. Gre za novost, na podlagi katere bo mogoče oblikovati temeljne usmeritve za organizacijo kriznega upravljanja znotraj SV. Zanimiva je tudi opredelitev pojma kriza z vidika vladne projektne skupine (Vuga in Ferlin, 2016, str. 3). Krizo razumejo kot: »razmere ogrožanja temeljnih družbenih vrednot, velike negotovosti in razmeroma kratkega časa za ukrepanje, ki presega odzivne zmožnosti posameznih resorjev ali podsistemov nacionalne varnosti«. Splošnejše opredelitve pojma krize, kot situacije, ki ogroža nacionalno ali mednarodno varnosti ter glavne družbene vrednote in zahteva takojšen odziv nanjo (Ekengren, Groenleer, 2006, 85-87), najdemo tudi v mednarodnem okolju (Nato, EU).

3 Več o tem Malešič, 2008, 116, Prezelj, 2005, str. 47-48. Prezelj (2005, 45-46) na primer v tem smislu razlikuje med enodimenzionalnimi in večdimenzionalnimi krizami, pri čemer je za reševanje enodimenzionalne krize z nizko kompleksnostjo dovolj, če jih rešuje ena dimenzija kriznega upravljanja. Pri večdimenzionalnih, visoko kompleksnih krizah pa pri reševanju sodeluje celoten spekter akterjev kriznega upravljanja.
} 
stanje, ko kriza dobi takšne razsežnosti, da je en akter ne zmore več samostojno upravljati in se upravljanje in vodenje odzivanja na krizo preneseta na Vlado $\mathrm{RS}^{4}$.

Poleg značilnosti kriz je za izoblikovanje procesa kriznega upravljanja pomembno tudi poznavanje poteka krize, ki običajno sledi določenemu vzorcu. Iz skice 1 je razviden potek krize, ki v svojem razvoju preide tri faze. V predkriznem času se pojavljajo grožnje, napetosti, težave, ki lahko vodijo do krize in ob ustreznem spremljanju situacije omogočijo prepoznavanje nastajanja krize in preventivno delovanje. Na točki izbruha krize prehaja krivulja $\mathrm{v}$ fazo krize, pri čemer nastaneta eskalacija razmer in vrhunec krizne situacije (v najbolj ekstremni obliki - vojna). Z umirjanjem situacije prehaja kriza v pokrizno obdobje, za katerega sta značilni stabilizacija in normalizacija stanja.

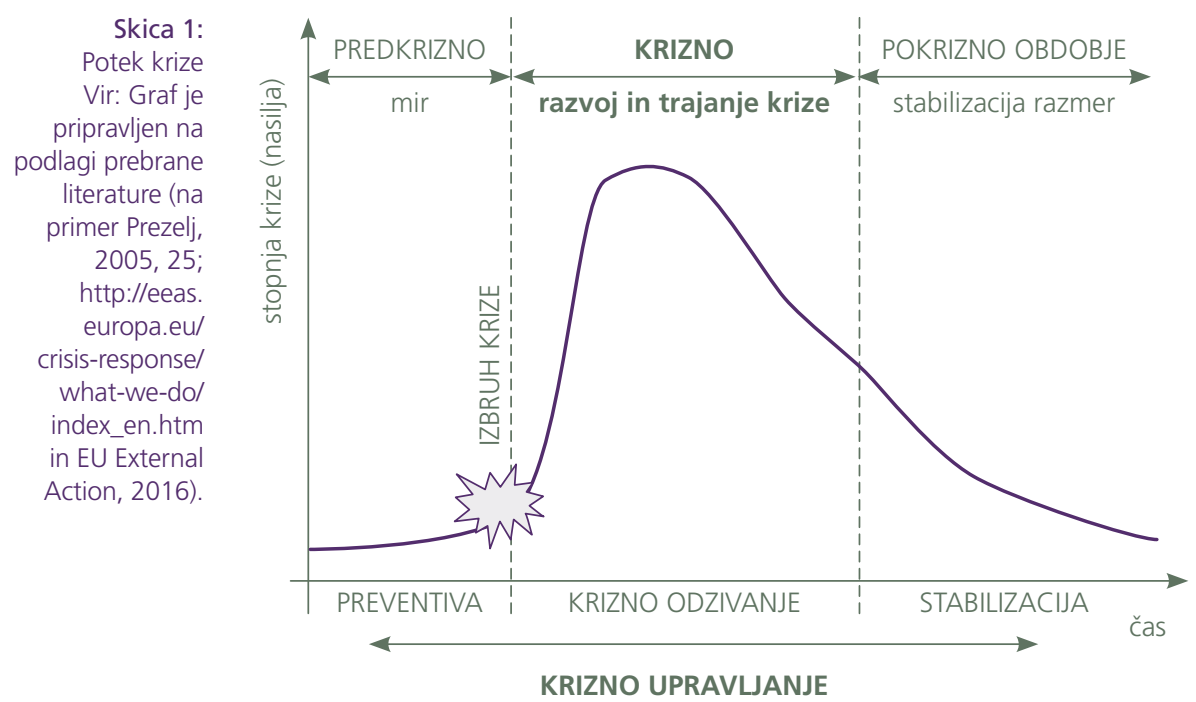

$\mathrm{Na}$ krizo se tesno navezujejo termini krizno upravljanje, krizno odzivanje in krizno vodenje. Terminološko na tem področju ni dorečeno, kdaj se uporabi določena besedna zveza, prav tako ni zaslediti enotne rabe pojmov pri obravnavanih subjektih $^{5}$.V prispevku je dosledno uporabljen termin krizno upravljanje, ki ga razumemo kot spremljanje krize pred nastankom ter kot preventivno odzivanje in ukrepanje ob izbruhu krize ter kot stabilizacijo po krizi.

\footnotetext{
4 Posledično delijo krize na področne (en resor samostojno obvladuje področje krize) in kompleksne krize (upravljanje se prenese na vlado, ki običajno aktivira strukturo kriznega upravljanja) (Vuga, Ferlin, 2016, 4).

5 Nato na primer dosledno uporablja termin »crisis management«, EU največkrat uporablja »crisis response" pa tudi »crisis management«, vladna projektna skupina uvaja pojem krizno upravljanje in vodenje (KUV) ipd. Tudi pri prevajanju »crisis management « ni mogoče najti enotne rabe, ali krizno upravljanje ali KUV.
} 
Krizno upravljanje je v slovenski literaturi temeljito opredelil Malešič $(2004,14)$, in sicer kot oblikovanje postopkov, dogovorov in odločitev, ki vplivajo na potek krize, in obsega organizacijo, priprave, ukrepe ter razporeditev virov za njeno obvladovanje. Krizno upravljanje običajno poteka v organizacijskem kaosu, pod pritiskom množičnih občil, V stresnih razmerah in ob pomanjkanju natančnih informacij. Spremembe narave in konteksta sodobnih kriz pa krizno upravljanje še otežujejo, saj so sodobne krize zelo kompleksne, učinkujejo prek različnih »meja« in so praviloma dolgotrajne ${ }^{6}$.

Izpostaviti je treba še eno pojmovno različico, in sicer krizno upravljanje in vodenje (KUV). Razlikovanje med avtorji, ki uporabljajo izraz krizno upravljanje, in avtorji, ki uporabljajo izraz KUV, je glede na proučeno le v tem, da tisti, ki dodajajo terminu še besedo vodenje, želijo posebej poudariti pomen vodenja v krizi, čeprav po drugi strani tudi tisti, ki besede vodenje ne uporabljajo pri opredeljevanju pojma, prav tako poudarjajo ključno vlogo vodenja. Sklepamo lahko, da je razumevanje izrazov vsebinsko izenačeno, za razliko od pojma krizno odzivanje, ki je po teoriji le del upravljanja (in vodenja).

\section{SISTEM KRIZNEGA UPRAVLJANJA V NATU IN EU}

\subsection{Krizno upravljanje v Natu}

Natov proces kriznega upravljanja (Nato Crisis Management Process - NCMP) je določen v Priročniku o Natovem sistemu odzivanja na krize (Nato Crisis Response System Manual- NCRSM) ${ }^{8}$, ki se praviloma posodablja vsako leto. Kot del operativnega procesa načrtovanja omogoča zavezništvu učinkovit pristop $\mathrm{k}$ preprečevanju konfliktov in uspešno upravljanje kriz. Zato je za zavezništvo zelo pomembno pravočasno izvajanje postopkov kriznega upravljanja, po možnosti že ob zaznavi prvih kazalnikov verjetnega izbruha krize, da se omogoči dovolj časa za sprejemanje usklajenih in najboljših rešitev.

NCMP je šestfazni postopek ocenjevanja situacije, posvetovanja, sprejemanja odločitev in odzivanja na (prihajajoče) krizne situacije.

\section{1. faza: kazalci in opozorila o morebitni prihajajoči krizi}

Proces spremljanja situacije in ogrožanja varnosti je stalen proces zavezništva, ki se neprekinjeno dopolnjuje $\mathrm{z}$ novimi podatki. Praviloma ga izvajajo

\footnotetext{
Nacionalna zakonodaja opredeljuje krizno upravljanje v drugem členu Uredbe o obrambnem načrtovanju (2013), ki pravi, da je krizno upravljanje enoten sistem organiziranosti, postopkov, aktivnosti in ukrepov z namenom učinkovitega obvladovanja kriznih razmer. Podobno opredeljuje termin tudi Vojaška doktrina.

Zaradi stopnje tajnosti dokumenta je vsebina NCMP predstavljena na podlagi javno dostopnih virov (zlasti Natovih spletnih strani http://www.nato.int/cps/en/natohq/official_texts_75565.htm? in http://www.nato.int/cps/ en/natolive/topics_49192.htm), priročnik NCRSM pa sta avtorja uporabljala zgolj kot oporo pri razumevanju koncepta Natovega procesa kriznega upravljanja.

$\&$ Zaradi stopnje tajnosti dokumenta je vsebina NCMP predstavljena na podlagi javno dostopnih virov, omenjeni priročnik je za avtorje zgolj opora pri razumevanju koncepta Natovega procesa kriznega upravljanja.
} 
obveščevalno-varnostne službe in službe za zgodnje opozarjanje ali kar članice. Njihova poročila predstavljajo izhodišče za prehod v naslednjo fazo in v posvetovalni proces Severnoatlantskega sveta (North Atlantic Council - NAC). Obstajajo štiri možnosti odziva na poročila: (1) sprejetje odločitve, da ni nujno nadaljnje ukrepanje; (2) odločitev, ki predvideva povečanje budnosti in pozornosti ter zagotavljanje dodatnih informacij v NAC; (3) NAC sprejme mnenje za začetek uvajanja določenih kriznih ukrepov na politični in varnostni ravni ter sprejetje preventivnih ukrepov $\mathrm{v}$ nujnih primerih. Ob takem odzivu se ustanovi civilno-vojaška delovna skupina za krizno odzivanje (Civil Military Task Force - CMTF); (4) prehod v fazi dve in tri s pripravo celovite ocene ogroženosti/krizne situacije.

\section{2. in 3. faza: ocena krizne situacije in oblikovanje mogočih oblik odzivanja}

NAC sprejme politično vojaško oceno (Political Military Estimate - PME) in poglobljeno obveščevalno analizo, ki je podlaga za pripravo strateškega vojaškopolitičnega načrta, s katerim se želijo doseči zastavljeno končno stanje in cilji zavezništva. Vrhovni poveljnik zavezniških sil za Evropo (Supreme Allied Commander Europe - SACEUR) mora pripraviti strateško oceno (SACEUR Strategic Assesment - SSA), ki je podlaga za pripravo strateškega vojaškega nasveta (Strategic Military Advice - SMA), ki ga pripravlja mednarodni vojaški štab (International Military Staff - IMS), odobri pa vojaški odbor (Military Committee - MC). SMA je podlaga za pripravo političnega nasveta s poglobljeno analizo varnostne situacije in za oblikovanje različic delovanja, ki predstavljajo tretjo fazo kriznega upravljanja. $\mathrm{V}$ tretji fazi se pripravijo začetne smernice (Nato Initiating Directive - NID) ${ }^{9}$, s katerimi se opredelijo cilji zavezništva, želeno končno stanje in ukrepi kriznega odzivanja. Ne glede na to, da se v tej fazi še ne oblikujejo odločitve zavezništva o vojaškem posredovanju, ker so še vse možnosti odprte za politično in diplomatsko presojo, SACEUR oblikuje možnosti vojaškega odziva (Military Response Options $\mathrm{MRO}$ ), članice pa formalno najavijo pripravljenost za sodelovanje.

\section{4. faza: načrtovanje}

Načrtovanje je najpomembnejša faza, pri kateri se oblikujejo ključni dokumenti za izvedbo odzivanja na situacijo. SACEUR v tej fazi razvije koncept operacij (Concept of Operations - CONOPS), ki mu sledi načrt operacij (Operations Plan - OPLAN). Dokumenta morata potrditi MC in NAC. Sočasno se začnejo procesi nabora sil in aktivacije. Na prehodu faze se oblikuje še izvršna direktiva (Nato Executive Directive - NED). Vse to je podlaga vojaški veji oblasti zavezništva, da preide $\mathrm{v}$ peto fazo kriznega upravljanja.

\section{5. faza: izvedba odločitev in direktiv NAC}

Po odobritvi vseh dokumentov in NED, ki predstavlja politično avtorizacijo, se začnejo posamezne operacije. Ves čas trajanja faze se periodično izvaja pregled

\footnotetext{
9 Na podlagi oblikovanih smernic lahko SACEUR začne operativno načrtovati, najprej s pripravo MRO.
} 
stanja (Periodic Mission Review - PMR), na podlagi katerega se odloča o prehodu v zadnjo fazo in o nadaljevanju operacije ali spremembah nekaterih ukrepov ${ }^{10}$.

\section{6. faza: vzpostavitev stabilnosti}

$\mathrm{V}$ tej fazi so pomembni prenos odgovornosti, dokončanje vojaških in drugih aktivnosti ter postopen umik Natovih sil z območja delovanja.

Nato je sistem odzivanja na krize (NCRS) in znotraj njega proces kriznega upravljanja (NCMP) začel posodabljati leta 2010 na podlagi sistemov za pripravljenost (Nato Alert System - NAS) in preventivo (Nato Precautionary System - NPS). Omogoča odziv v obliki celovitega pristopa vseh članic in hkrati ostaja dovolj prožen za nenehno prilagajanje spremembam v okolju.

\subsection{Krizno upravljanje v EU}

Po uveljavitvi Lizbonske pogodbe leta 2009 se proces kriznega upravljanja EU vključuje v skupno zunanjo in varnostno politiko (SZVP) ter znotraj nje v skupno varnostno in obrambno politiko (SVOP). Namen SVOP je krepitev civilnih in vojaških zmogljivosti EU za preprečevanje konfliktov in krizno upravljanje. Z zagotavljanjem učinkovitega odzivanja na krize prehaja EU iz »celostnega pristopa« v »celostno ukrepanje«, ki je prav tako uveljavljeno v vseh fazah razvoja in upravljanja kriz (od prvih informacij o prihajajoči krizi do pokrizne obnove in stabilizacije) (Skupna zunanja in varnostna politika, 2016).

Osrednjo vlogo v kriznem upravljanju EU imata Evropska služba za zunanje zadeve (The European External Action Service - EEAS) in Oddelek za krizno odzivanje in operativno načrtovanje (Crisis Response and Operational Coordination Department). Odgovorna sta za aktivacijo sistema EEAS za krizno odzivanje, ki je sestavljen iz treh elementov: Osnovne krizne celice (Crisis Platform), Situacijske sobe (EU Situation Room) in Odbora za krizno upravljanje (Crisis Management Board). Ključni akterji na instrumentalno-upravni ravni kriznega upravljanja EU, ki sestavljajo t. i. Crisis Platform, so: Direktorat za krizno upravljanje in načrtovanje (Crisis Management and Plans Directorate - CMPD) ${ }^{11}$, Vojaški štab EU (EU Military Staff - EUMS), situacijski center EU (SitCen), Vojaški odbor (EU Military Committee - EUMC) in druge nujne komisije EU, Civilne zmogljivosti za načrtovanje in izvajanje operacij (Civilian Planning and Conduct Capability - CPCC), Center za operacije EU (EU Operations Centre) in Center za obveščevalne analize (Inteligence Centre). Predsedujoča vzpostavljenemu sistemu je Visoka predstavnica EU ali tudi izvršni direktor EEAS (ESG). Države članice se vključujejo z osebjem v stalnem

\footnotetext{
${ }^{10}$ Isaf in Kfor sta primera operacij, ki sta v peti fazi procesa kriznega upravljanja.

${ }^{\prime \prime}$ CMDP je center SVOP, odgovoren za integrirano civilno-vojaško načrtovanje v EEAS. Vpleten je v vse strukture kriznega upravljanja EU in je glavni sestavni del odločanja v EEAS. CMDP deluje pod nadzorom Političnega in varnostnega odbora EU (Political and Security Committee - PSC), ki ga sestavljajo predstavniki vseh držav članic. Hkrati je strokovni in podporni organ visoki predstavnici EU (EU External Action, 2016).
} 
predstavništvu pri EU (in Natu) ter neposredno iz države, z obrambnega ministrstva in ministrstva za zunanje zadeve (Blagonič, 2014, 40, in EU External Action, 2016) ${ }^{12}$.

Znotraj SVOP izvaja EU integrirano (civilno-vojaško) strateško načrtovanje za razvoj možnosti delovanja EU v kriznih razmerah. Predstavljene so v t. i. Konceptu kriznega upravljanja (Crisis Management Concept - CMC), ki ga potrdijo ministri EU in je podlaga za odločanje v Svetu EU. EU je od sprejema Lizbonske pogodbe do danes zelo napredovala $\mathrm{v}$ smeri ureditve področja kriznega upravljanja, tako na organizacijski kot procesni ravni. Z oblikovanjem SZVP/SVOP je razvila koncept sodelovanja med državami v postopkih upravljanja kriz, kar ji omogoča aktivno sodelovanje pri normalizaciji stanja v kriznih situacijah po svetu. Največji napredek $\mathrm{v}$ sodelovanju in povezovanju mednarodne skupnosti $\mathrm{v}$ reševanju kriz pa še vedno pomeni t. i. aranžma Berlin plus ${ }^{13}$, ki EU omogoča dostop in uporabo Natovih zmogljivosti načrtovanja in njihove uporabe na področju kriznega upravljanja.

\subsection{Krizno upravljanje v Republiki Sloveniji}

V Sloveniji je po sedanji ureditvi vsak resor odgovoren za reševanje kriz na svojem področju, njihovo delo pa usklajuje Vlada RS. Njen politični svetovalni organ je Svet za nacionalno varnost (SNAV) ${ }^{14}$, katerega operativni del predstavlja Sekretariat SNAV (SSNAV), tehnično podporo vladi zagotavlja Nacionalni center kriznega upravljanja (NCKU) ${ }^{15}$, znotraj katerega deluje tudi Medresorska analitična skupina (MAS), ki zagotavlja strokovno podporo odločevalnim organom ob pojavu krize. Celotna struktura v Sloveniji je usmerjena zgolj v krizno odzivanje, zaščito kritične infrastrukture in sprejemanje mehanizmov za reševanje kriz.

$\mathrm{Na}$ pomanjkljivosti nedokončanega oblikovanja sistema kriznega upravljanja opozarjajo tako strokovnjaki s področja kriznega upravljanja ${ }^{16}$ kot tudi ugotovitve praktičnih izkušenj RS s periodičnih vaj kriznega upravljanja znotraj Nata in EU. Vlada RS je za reševanje tega problema leta 2016 imenovala že omenjeno vladno

\footnotetext{
12 Situacijska soba predstavlja krizni center EU, ki zagotavlja neprekinjeno opazovanje in spremljanje situacije. Odbor za krizno upravljanje usklajuje aktivnosti EU med krizo. Del oddelka kriznega odzivanja je tudi svetovalni oddelek za krizno odzivanje, ki ima dve vlogi: pomaga pri koordinaciji kriznih politik vseh članic in vodi usklajevanje aktivnosti med članicami. Vzpostavitev takšnega mehanizma omogoča izvajanje celovitega pristopa in celovitih akcij ter omogoča planiranje vnaprej kot tudi sprejemanje ad hoc rešitev. Struktura zagotavlja politične in strateške usmeritve za EEAS.

${ }_{13}$ Dogovor med Natom in EU (Berlin, 16. 12. 2002) v zvezi s sklepi washingtonskega vrha zavezništva leta 1999, da lahko EU na podlagi t. i. pogoja "Right of First Refusal" uporablja določene Natove vojaške zmogljivosti, če zavezništvo nima namena posredovati v operaciji kriznega odzivanja, za katero kaže zanimanje EU.

${ }^{14}$ Naloge SNAV znotraj sistema kriznega upravljanja so: svetovanje vladi pri sprejemanju ukrepov s področja nacionalne varnosti, usklajevanje mnenj ministrstev in drugih državnih organov s področja nacionalne varnosti, ocenjevanje varnostnega tveganja ogrožanja države in dajanje mnenj $k$ vprašanjem s področja nacionalne varnosti (Odlok o SNAV,Uradni list 70/2013).

${ }^{15}$ NCKU je organiziran na MO, njegovo stalno jedro pa deluje neprekinjeno. Naloga NCKU je zagotovitev tehnične, komunikacijsko-informacijske podpore delovanju Vlade RS v kriznih razmerah, skladno z Zakonom o izrednem in vojnem stanju ali ob pojavih kriz v okolju, ki ogrožajo nacionalno varnost. Organizacijo naloge, delo ipd. določa Odredba o organizaciji in delovanju NCKU.

${ }^{16}$ Malešič, 2008; Vuga, Ferlin, 2016; Prezelj, 2005, itn.
} 
projektno skupino, da razišče možnosti (pre)oblikovanja strukture KUV na ravni države in izpopolnitve postopkov ter delovanja kriznega upravljanja in drugih mehanizmov kriznega upravljanja, primerljivih z uveljavljenimi sistemi v Natu in EU. Pomembna naloga projektne skupine se nanaša tudi na iskanje ustreznih normativnopravnih rešitev, ki bi zagotavljale dovolj dobre (celovite in prožne) sistemske podlage za učinkovito delovanja kriznega upravljanja na nacionalni ravni.

\subsubsection{Predlog strukture KUV pri Vladi RS ${ }^{17}$}

Predlog nove strukture KUV se opira na nujne funkcije ${ }^{18}$ za upravljanje kriz, na omejenost finančnih in kadrovskih virov ter na zagotavljanje maksimalne učinkovitosti. Normativnopravno naj bi bila umeščena v zakon o vladi, natančneje pa bi njegovo delovanje urejal podzakonski akt (na primer uredba o kriznem upravljanju in vodenju). Struktura bi imela en stalni organ, drugi pa bi se aktivirali ob pojavu krize. Glavni cilj takšne ureditve je zagotavljanje optimalnega in usklajenega delovanja vseh resorjev ter podsistemov nacionalnovarnostnega sistema. Sedanja telesa (SNAV, SSNAV, MAS in NCKU) bi povezala v skupno strukturo in jih dopolnila s stalno operativno skupino pri SSNAV ter medresorsko skupino za spremljanje situacije in usklajevanje. Takšna struktura bi bila umeščena vertikalno, h generalnemu sekretariatu vlade ali v kabinet predsednika vlade. Zato bi bilo smiselno okrepiti in zvišati stopnjo institucionaliziranosti funkcije svetovalca predsednika vlade za nacionalno varnost, ki je hkrati vodja SSNAV ${ }^{19}$. Ob krizi bi bila tako vnaprej določena oseba, ki bi prevzela usklajevalno vlogo, po pooblastilu vlade pa tudi vodstveno ${ }^{20}$. Predlagana struktura KUV pri vladi ne posega v pristojnosti ali delovanje resorjev in podsistemov nacionalnovarnostnega sistema, namenjena je le podpori odločanja Vlade RS pri odzivanju na kompleksne krize.

Postopek KUV po tej strukturi bi začela izvajati Vlada RS z aktivacijo NCKU. Vladi bi stalno obveščenost zagotavljal SSNAV, ki samostojno odloča o zadevah ali odločanje s pooblastilom preda vodji SSNAV. SSNAV je stalno telo, ki se ob pojavu krize preoblikuje v operativno-usklajevalno telo in prevzame (vodja SSNAV) ključno krizno usklajevanje med resorji. SNAV ostaja posvetovalno telo, ki pa se po potrebi tudi razširi na nestalne resorje. Medresorska analitična skupina MAS in Medresorska skupina za spremljanje situacije in usklajevanje (MS3U) morata delovati skupaj in usklajeno ter pripraviti enotno poročilo za SSNAV (že v miru) ter scenarije razvoja dogodkov in rešitev. Predlog ukrepov sprejme ožja skupina

\footnotetext{
${ }^{17}$ Poglavje temelji na prispevku avtoric Vuga in Ferlin (2016, 9-32), v katerem predstavljata koncept vladne projektne skupine o vzpostavitvi celovite strukture KUV pri Vladi RS.

${ }^{18}$ Funkcije, nujne za upravljanje kompleksnih kriz, so spremljanje situacije in ogroženosti, analiziranje in predvidevanje, svetovanje, odločanje, usklajevanje in vodenje, komuniciranje, enotna pokrizna analiza, podporne funkcije (na primer psihosocialna pomoč) (Vuga, Ferlin, 2016, 13).

19 Kot drugo, a slabšo možnost sestavljavci sistema predlagajo, da vodenje v krizi prevzame minister ali državni sekretar, na čigar področju je kriza izbruhnila.

${ }^{20}$ Predlagana funkcija zahteva visoko stopnjo strokovnega znanja, izkušenj, posebnih osebnostnih lastnosti in prevzemanje odgovornosti. Treba je določiti pogoje za imenovanje na mesto vodje SSNAV in hkrati svetovalca predsednika vlade za nacionalno varnost. Izpolnitev teh pogojev bi pripomogla pri vzpostavitvi sistema dolgoročnega oblikovanja tako imenovanih kriznih vodij (Vuga, Ferlin, 2016, 21).
} 
svetovalcev vodje SSNAV. Vodja SSNAV jih pošlje v obravnavo SNAV, ki predstavi svoje mnenje, predloge in dopolnila. Nato vodja SSNAV predlog rešitev in ukrepov posreduje predsedniku vlade in vladi.

Predstavljena ureditev področja kriznega upravljanja pomeni najboljšo mogočo rešitev $\mathrm{v}$ tem trenutku, tako $\mathrm{v}$ nacionalnem kot $\mathrm{v}$ mednarodnem okolju. Upošteva nacionalne omejitve in zaveze, ki izhajajo iz mednarodnih integracij ter omogoča podsistemom nacionalne varnosti, ki se spoprijemajo s krizo, da uskladijo svoje koncepte z njim.

\section{UMEŠČENOST SLOVENSKE VOJSKE V SISTEMIH KRIZNEGA UPRAVLJANJA}

\subsection{Analiza pravnih virov s področja kriznega upravljanja}

$\mathrm{Z}$ analizo primarnih virov smo ugotavljali normativno urejenost področja kriznega upravljanja na nacionalni ravni. Obsegala je analize Ustave RS, aktualnega Zakona o obrambi in novele Zakona o obrambi, Zakona o varstvu pred naravnimi in drugimi nesrečami, Resolucije o strategiji nacionalne varnosti, Obrambne strategije RS, Vojaške doktrine, Strateškega pregleda obrambe 2016, Strategije sodelovanja RS v mednarodnih operacijah in na misijah, Uredbe o organizaciji in delovanju Nacionalnega centra za krizno upravljanje in Uredbe o obrambnem načrtovanju. Zaradi obsežnosti analize $\mathrm{v}$ nadaljevanju izpostavljamo zgolj njene ključne ugotovitve, pomembne za oblikovanje sklepov.

Skupno vsem dokumentom je, da poudarjajo težo usklajenega in celovitega pristopa (nacionalno in mednarodno) k načrtovanju upravljanja kriz in reševanju nastalih kriznih situacij, ne glede na meje in naravo krize. Zakonodaja ne omejuje sodelovanja SV v kriznih situacijah, vendar je njena aktivacija odvisna od drugih subjektov v nacionalnovarnostnem sistemu (Civilna zaščita, predsednik RS ipd.) in je pretoga za hitro odzivanje. Pregled zakonodaje dokazuje, da procesi in postopki znotraj SV in MO RS niso usklajeni niti jasno opredeljeni. Ni opredeljenih nosilcev nalog ali postopkov, med posameznimi segmenti ni logičnih povezav, določeni deli odločanja in načrtovanja v krizi pa sploh niso zaznani niti razviti. Proces kriznega upravljanja je zastavljen kot ad hoc proces kriznega odzivanja, saj postopki pred krizo in po njej niso institucionalizirani, zato se v odločilnih trenutkih SV kot ustanova pogosto znajde $\mathrm{v}$ precepu in je edino mogoč le še odziv. V proučevanih predpisih ni nikjer zaslediti navajanja Natovih ali EU-dokumentov, ki bi morali predstavljati vhodne parametre za organiziranost kriznega upravljanja na nacionalni ravni. Sklepamo lahko, da proces kriznega upravljanja v SV z vidika analize pravnih virov ni opredeljen. Pomembna je tudi ugotovitev, da je proces kriznega upravljanja v RS parcialno in razpršeno zajet v vseh zgoraj navedenih pravnih aktih, manjka pa celovita normativnopravna rešitev, ki bi jasno opredelila in določila pravila delovanja vseh akterjev kriznega upravljanja, na kar opozarja tudi vladna projektna skupina. 


\subsection{Slovenska vojska v sistemu kriznega upravljanja}

Koncept kriznega odzivanja na obrambnem področju je bil oblikovan na podlagi 16. člena Zakona o obrambi in sklepa Vlade RS o pripravah za izvajanje Natovih ukrepov ob krizah ${ }^{21}$. Skladno s tem konceptom deluje v upravnem delu Ministrstva za obrambo, Direktoratu za obrambne zadeve, Oddelek za obrambno krizno načrtovanje, ki usklajuje in izvaja naloge kriznega načrtovanja na obrambnem področju ter sodeluje pri ocenjevanju tveganj in ogrožanja nacionalne varnosti. Na oddelku se načrtujejo pogoji za delo predsednika države, Vlade RS in Državnega zbora RS $\mathrm{v}$ izrednih razmerah in vojni. Tam se tudi usklajujejo priprave državnih organov za zaščito kritične infrastrukture $v$ državi. Za zagotavljanje civilnih zmogljivosti $\mathrm{v}$ podporo SV in medresorsko koordinacijo pa je bil $\mathrm{v}$ omenjenem direktoratu ustanovljen Oddelek za civilne zmogljivosti in krizno odzivanje. Na področju kriznega odzivanja izvaja aktivnosti odziva na krize znotraj EU in Nata. Strokovno pomaga izvajalcem ukrepov NCRS in jih podpira pri kriznem komunikacijskem informacijskem sistemu, ki je del t. i. informacijskega sistema v podporo odločanju (ISPO). Podpira delovanje Natovega Odbora za civilno krizno načrtovanje (Civil Emergency Planning Committee - CEPC).

SV se vključuje v sistem varstva pred naravnimi in drugimi nesrečami s sodelovanjem in izvajanjem nalog pri zaščiti in reševanju ob naravnih in drugih nesrečah, skladno s svojo organiziranostjo in opremljenostjo (37. člen ZObr). Za to ima SV, na podlagi državnih načrtov zaščite in reševanja, za posamezno vrsto nesreče pripravljene dokumente (načrte delovanja SV) za ukrepanje ob velikem požaru, potresu, poplavi, uporabi orožja za množično uničevanje, terorizmu ipd., ki so združeni v načrtu Vihra. O sodelovanju SV pri nalogah zaščite in reševanja odloča Vlada RS, v nujnih primerih pa minister na predlog poveljnika Civilne zaščite RS oziroma načelnika GŠSV po pooblastilu ministra.

S Standardnim operativnim postopkom 03-003 (SOP) za krizno organiziranje GŠSV iz leta 2011 so opredeljena izhodišča za načrtovanje, organiziranje in vodenje GŠSV ob pojavu kriznih razmer. Dokument zagotavlja tudi usklajenost funkcijskih področij in usmeritve podrejenim poveljstvom ter enotam za vzdrževanje zahtevane ravni pripravljenosti SV. V njem so sicer jasno zapisane naloge po sektorjih in samostojnih poveljstvih, vendar brez opredelitve postopka kriznega upravljanja znotraj kabineta načelnika GŠSV oziroma SV (SOP, 03-003). Težava dokumenta je tudi dejstvo, da je bil napisan pred letom 2012, ko je bila izvedena zadnja transformacija SV. Tudi s tega vidika bi bilo treba vsebine pregledati in jih posodobiti. Za boljše razumevanje aktualnega delovanja in strukture SV je treba izpostaviti, da se delovanje SV po transformaciji usmerja prek Združenega operativnega centra $(\mathrm{ZOC})^{22}$, ki je jedro za organizacijo operativnega poveljevanja. Leta 2017 se struktura in obseg SV prilagajata ugotovitvam in predlaganim ukrepom Strateškega pregleda obrambe

\footnotetext{
${ }^{21}$ Sklep Vlade Republike Slovenije, št. 810-02/2002-2, z dne 16. 1. 2003.

${ }^{22}$ Med glavne naloge ZOC poleg drugih spadata tudi vodenje in usklajevanje uporabe zmogljivosti in enot $S V v$ sistemu varstva pred naravnimi in drugimi nesrečami ter ob njihovem aktiviranju v krizi.
} 
(2016), pri katerem bo med drugim do izraza prišla tudi ponovna vzpostavitev funkcije načelnika štaba GŠSV in Poveljstva sil. Te strukturne spremembe SV lahko z ustrezno in načrtno umestitvijo njihove vloge, kot bo prikazano v nadaljevanju tega prispevka, bistveno pripomorejo $\mathrm{k}$ sistemskim rešitvam in učinkovitosti delovanja SV na področju kriznega upravljanja.

Predstavljeni dokumenti (predvsem SOP) dobro opredeljujejo postopke kriznega odzivanja in namenskega organiziranja za delovanje v krizah, medtem ko se koncepta kriznega upravljanja ne lotevajo. Zato je treba sedanjo strukturo vzeti kot podlago, na kateri temelji celovit in učinkovit sistem kriznega upravljanja v SV.

\subsection{Ugotovitve Slovenske vojske z vaj kriznega upravljanja}

Cilj priprav in izvedbe vaj kriznega upravljanja na obrambnem področju v RS je preverjanje postopkov, usklajevanja in odziva SV, državnih in drugih organov ob zaostrovanju varnostnih razmer v mednarodnem in nacionalnem okolju. Na vajah se preverjajo rešitve, iščejo slabosti in uveljavljenost načel kriznega upravljanja EU ter Nata in povezljivost sistemov.

V prispevku so analizirane Natove (CMX) in EU (CME)-vaje kriznega odzivanja od leta 2012 ter vaja Vodstvene obrambno-zaščitne vaje Pomlad 2011. Skupaj gre za šest vaj, nekatere vmes niso bile izvedene (CMX13, CMX14 je bila izpeljana 2015), nekaterih pa se RS ni udeležila (vaji EU MILEX 2013 in 2015). Analiza se naslanja predvsem na zapis pomembnejših dobrih in slabih praks z omenjenih vaj ter podatke, ki so povezani s predmetom proučevanja in bi lahko koristno pripomogli k sklepnim ugotovitvam.

\begin{tabular}{|c|c|}
\hline Dobre prakse: & Slabe prakse: \\
\hline $\begin{array}{l}\text { - vzpostavitev krizne sobe Direktorata za obrambne } \\
\text { - zadeve; } \\
\text { maje so vedno dobro izvedene zaradi osebne } \\
\text { motiviranosti, dobre usposobljenosti, kolektivnega } \\
\text { - dobro funkcijsko in medsektorsko sodelovanje, ki } \\
\text { bi moralo biti sistemsko urejeno; } \\
\text { - častniki za povezavo; } \\
\text { - sodelovanje s stalnimi predstavništvi RS v tujini; } \\
\text { - oblikovanje skupnega portala, na primer »Pomlad } \\
2011 \text { «, »Acid«, ki omogoča hranjenje in analizo } \\
\text { informacij na enem mestu, vendar je to mogoče } \\
\text { le znotraj MO RS, in ne širše; } \\
\text { - dobro komuniciranje in izmenjava informacij na } \\
\text { taktični in operativni ravni; } \\
\text { - pregleda dnevnega dogajanja NCKU, kar } \\
\text { omogoča celovit pregled in obveščenost o poteku } \\
\text { aktivnosti; } \\
\text { - odziv nacionalnovarnostnega sistema na pojav } \\
\text { hibridnega vojskovanja je pospešil ustanovitev } \\
\text { skupine za kibernetsko delovanje znotraj SV; } \\
\text { - vzpostavitev videokonferenčnih povezav in sej. }\end{array}$ & $\begin{array}{l}\text { - nejasnosti glede razmejitev pristojnosti za } \\
\text { odločanje na politični in vojaški ravni; } \\
\text { - prepočasno sprejemanje ukrepov kriznega } \\
\text { odzivanja (Natovih in vladnih); } \\
\text { - neopredeljeni postopki štaba ob uvedbi kriznega } \\
\text { upravljanja (GŠSV nima jasno določenega nosilca } \\
\text { štabnega procesa niti nima svojega situacijskega } \\
\text { centra za zadovoljivo podporo in spremljanje } \\
\text { situacije); } \\
\text { - prepočasno kroženje informacij med političnim } \\
\text { odločanjem, strateško in izvedbeno ravnijo; } \\
\text { - komunikacijsko-informacijska podpora ne } \\
\text { omogoča prenosa tajnih podatkov med akterji, ni } \\
\text { povezljiva z Natovim sistemom; } \\
\text { - pomanjkanje ustreznih pravnih podlag za } \\
\text { delovanje SV znotraj kriznega upravljanja; } \\
\text { - organizacijsko-mobilizacijski razvoj ni ustrezen, } \\
\text { dopolnjevanje SV ob pojavu kriz je predolgotrajen } \\
\text { proces, dodatno dopolnjevanje SV je mogoče šele } \\
\text { ob uvedbi kriznih razmer; } \\
\text { - ni zagotovljenih prostorskih razmer, da bi GŠsV } \\
\text { deloval centralno - delovanje z mirnodobnih } \\
\text { lokacij se je izkazalo kot neustrezno in razpršeno. }\end{array}$ \\
\hline
\end{tabular}




\subsection{Analiza kriznega odzivanja SV v praksi}

\section{Žled 2014}

Zaradi razsežnosti naravne nesreče je bila aktivirana tudi SV, ki je vidno prispevala $\mathrm{k}$ reševanju krize in odpravljanju posledic ter normalizaciji stanja.

\begin{tabular}{|c|c|}
\hline Dobre prakse: & Slabe prakse: \\
\hline $\begin{array}{l}\text { - hitri odzivnost in sposobnost izvedbe (vojaškega) } \\
\text { procesa odločanja na taktični ravni ter } \\
\text { prevzemanje iniciative v primerjavi z drugimi } \\
\text { subjekti sistema ZRP sta prednosti vojske, ki sta v } \\
\text { praksi pogosto premalo uporabljeni; } \\
\text { - častniki za povezavo (v civilnem okolju in drugih } \\
\text { strukturah ZRP); } \\
\text { - usposobljenost in motiviranost pripadnikov SV; } \\
\text { - vključitev vojaških strokovnjakov v strukturo } \\
\text { kriznega odzivanja, predvsem v obliki delovanja } \\
\text { na terenu (psihologi, pravniki, veterinarji ipd.); } \\
\text { - zbiranje podatkov o stanju neposredno na terenu } \\
\text { (oblikovanje skupin za pridobivanje podatkov s } \\
\text { terena in dajanja pomoči prebivalstvu). }\end{array}$ & $\begin{array}{l}\text { - enote SV so bile pripravljene nekaj dni pred } \\
\text { aktivacijo, na teren so bile poslane šele četrti dan } \\
\text { po pojavu krize; } \\
\text { - v praksi na terenu ni vedno določen subjekt, ki bi } \\
\text { vodil koordinacijo med vsemi subjekti (problem } \\
\text { povezanosti in usklajenosti); } \\
\text { - ukazi nadrejenih so prihajali prepozno (problem } \\
\text { pravočasne priprave na nalogo); } \\
\text { - delovanje SV ne sme biti prepuščeno iniciativam } \\
\text { županov in odvisno od organiziranosti civilne } \\
\text { zaščite na lokalni ravni; } \\
\text { - pomanjkanje specifičnega strokovnega kadra (na } \\
\text { primer upravljavci motornih žag); } \\
\text { - posamezniki na terenu se hitro ujamejo, } \\
\text { usklajevanje delovanja v kriznih štabih pa ni } \\
\text { utečeno (slab odzivni čas); } \\
\text { - odsotnost enotnega komunikacijsko- } \\
\text { informacijskega sistema. }\end{array}$ \\
\hline
\end{tabular}

Vir: povzeto po Škerbinc idr., 2014, 83-86.

Kljub dobro opravljenem delu je glede na opravljeno analizo ostalo še veliko prostora za izboljšave, predvsem v smislu povečanja učinkovitosti in racionalizacije sistema kriznega upravljanja kot celovitega sistema, ki izrablja vse možnosti, ki jih ima na razpolago (tudi pri uporabi zmogljivosti SV). 


\section{Migrantska kriza 2015-2016}

V RS so se začeli procesi »operacije migrant«, ki bi jo lahko označili tudi kot krizno odzivanje. To potrjujeta tudi dopolnitev Zakona o obrambi in razširitev pooblastil SV s členom 37. a ob izrednih (kriznih - op. avtorja) razmerah na zaostreno varnostno situacijo $^{23}$. Dobre in slabe prakse so povzete na podlagi analize delovanja SV v podporo Policiji in iz izkušenj v operaciji migrant.

\begin{tabular}{|c|c|}
\hline Dobre prakse: & Slabe prakse: \\
\hline $\begin{array}{l}\text { - centralizirano vodenje (SV, MNZ, Civilna zaščita } \\
\text { (CZ)) vseh aktivnosti in nalog na enem mestu; } \\
\text { - priprava skupnega operativno-taktičnega načrta } \\
\text { sodelovanja SV in Policije; } \\
\text { - pravočasno napisana pravila delovanja SV v } \\
\text { podporo Policiji pri širšem varovanju državne } \\
\text { meje, ki jih je sprejela Vlada RS; } \\
\text { - častniki za povezavo v ZOC, pri Policiji in CZ; } \\
\text { - usklajevanje nalog, preneseno na ZOC, linija PINK } \\
\text { se je prilagajala glede na naloge; } \\
\text { - vzpostavitev operativnega (inženirskega) centra za } \\
\text { strokovno svetovanje in spremljanje situacije; } \\
\text { - vlogo koordinatorja dela na terenu prevzameta } \\
\text { nosilni brigadi (podpora CZ in Policiji), } \\
\text { sodelovanje s Policijo je bilo dobro, želja po } \\
\text { usklajenem delu velika; } \\
\text { - dnevni ukazi ZOC so bili prek častnikov za } \\
\text { povezavo usklajeni z nosilnimi enotami. }\end{array}$ & $\begin{array}{l}\text { - štabna organiziranost GŠSV in sestava sil, ki so } \\
\text { predvidene z obrambnimi mobilizacijskimi načrti, } \\
\text { nestalnost določenih štabnih organov in nosilcev } \\
\text { funkcijskih področij; } \\
\text { - različni sistemi PINK (Policija, SV, CZ); } \\
\text { - umeščenost ZOC se je izkazala za težavno v } \\
\text { strukturi PINK, lokacijska razdrobljenost GŠSV in } \\
\text { specialističnih enot (inženirskih, JRKBO ipd.) ne } \\
\text { omogoča optimalnega kriznega odzivanja; } \\
\text { - odziv PPRS ni dosegel pričakovanega; } \\
\text { - neustrezna zakonska urejenost področja kriznega } \\
\text { upravljanja in ad hoc delovanje; } \\
\text { - ni bilo skupnega usposabljanja s Policijo } \\
\text { za izvajanje skupnih nalog (slabost je bila } \\
\text { odpravljena šele, ko je bila zaznana); } \\
\text { - ni bilo zaznati preventivnega in obveščevalno- } \\
\text { informativnega delovanja pred krizo in po njej; } \\
\text { - slabo komuniciranje z javnostjo in obveščanje. }\end{array}$ \\
\hline
\end{tabular}

Obe opravljeni analizi izkušenj nakazujeta ugotovitev, ki jo je Kotnik $(2008,211)$ izpostavil že leta 2008, da je treba povečati in sistemsko izpopolniti vlogo SV V sistemu nacionalnega kriznega upravljanja, saj je učinek njenih zmogljivosti pri odpravljanju večine kriz in njihovih posledic nenadomestljiv.

\subsection{Ideja koncepta kriznega upravljanja SV}

Ideja koncepta kriznega upravljanja v SV je v organizacijskem in procesnem smislu oblikovana na podlagi teoretičnih in normativnih izhodišč, ugotovitev že opravljenih raziskav $^{24}$, primerjalnih analiz ter drugih dejstev, zapisanih v prispevku.

\section{Organizacijska struktura}

Pri vzpostavitvi učinkovitega kriznega upravljanja ne smemo zapostaviti pomena kriznega vodenja znotraj procesov upravljanja kriz. Pri vzpostavitvi koncepta KUV ${ }^{25}$ v SV bi bilo smiselno upoštevati ugotovitve Boin, Hart, Stern (2015, str. 1-18), in

\footnotetext{
${ }^{23}$ Ne moremo pa trditi, da je šlo za proces kriznega upravljanja, saj je skupna ugotovitev vseh, ki so proučevali operacijo migrant, da RS ni upoštevala zgodnjih znakov in groženj pred eskalacijo krize in je glavnino migrantskega vala pričakala nepripravljena.

${ }^{24}$ Na primer Malešič, 2008; Vuga, Ferlin, 2016; Prezelj, 2005.

${ }_{25}^{25}$ Termin, kot ga pri prenavljanju načina upravljanja kriz v RS uvajata tudi Vuga in Ferlin (2016).
} 
sicer, da imajo voditelji posebno odgovornost ukvarjanja s krizami v vseh njihovih fazah $^{26}$. Na ravni SV je ta organ odločanja ob pojavu kriz načelnik GŠSV ${ }^{27}$.

Naslednji ključni korak izhaja iz ugotovitev avtoric Vuga in Ferlin (2016, 7), ki ugotavljata, da imajo vse države (zajete $\mathrm{v}$ analizi vladne projektne skupine) usklajevalni organ, ki upravlja kompleksne krize. Tudi v SV bi bilo smiselno slediti tem ugotovitvam in pregledati obstoječe rešitve ter jih, kot smo že omenili, ob postavljanju nove strukture in obsega SV posodobiti, skladno s konceptom strukture KUV pri Vladi RS. Aktivnosti usklajevanja in zagotovitve ustrezne podpore pri odločanju v procesu kriznega upravljanja bi se morale z vidika hierarhičnosti in funkcionalnosti najprej ustrezno uravnotežiti med načelnikom GŠSV, načelnikom štaba GŠSV in poveljnikom Poveljstva sil SV. Znotraj kabineta načelnika GŠSV je treba na novo vzpostaviti funkcijo koordinatorja za strateške komunikacije (StratCom), dolžnost, ki bi morala biti stalna in formacijsko določena.

Načelnik štaba bi imel zaradi lažje operacionalizacije del možnost oblikovanja operativne skupine, nestalnega organa, ki bi se oblikoval po potrebi oziroma bi se zaradi izmenjave informacij in usposabljanja skliceval periodično tudi $\mathrm{v}$ miru. Skupino (na nacionalni ravni bi lahko to skupino primerjali s SSNAV) bi sestavljali strokovnjaki vseh glavnih funkcijskih področij GŠSV, strokovni organi, civilni strokovnjaki, podporne službe ipd. Med krizo bi skupina delovala z ene lokacije (takšna lokacija bi lahko bila z vidika funkcionalnosti bližina načelnika štaba GŠSV ali lokacija Poveljstva sil SV) ${ }^{28}$.

Nadalje je treba pri oblikovanju koncepta kriznega upravljanja temeljito razmisliti o naboru sil in zmogljivosti za ustrezno krizno upravljanje. Nujno bi bilo upoštevati dejstvo, da se ob spoprijemanju s krizami vedno srečujemo s kadrovskimi težavami (pomanjkanje kadra, neuspešnost vpoklica pogodbene rezerve ipd.). Poleg motiviranja pogodbene rezerve in pridobivanja novega kadra v vojaško organizacijo bi bilo smiselno razpravljati tudi o načinih in pogojih ponovne uvedbe služenja vojaškega roka ob trajnejših krizah, ki bi zahtevale množični vpoklic.

$\mathrm{Na}$ podlagi izvedenih analiz lahko izpostavimo, da lahko element izmenjave informacij, usklajevanja in poročanja, poleg formalnih voditeljev in odločevalcev, zelo učinkovito opravljajo častniki za povezavo. Čeprav ni nujno, da je ta funkcija stalna, bi morali biti častniki za opravljanje te funkcije v kriznih razmerah posebej usposobljeni že v mirnodobnem času. Prav tako bi bilo nujno, da SV imenuje

\footnotetext{
${ }^{26}$ Zaradi tega razčlenijo pet kritičnih strateških nalog kriznega vodenja: osmišljanje/opredelitev krize, sprejemanje odločitev, oblikovanje pomena krize, končanje krize in učenje iz naučenih lekcij (Boin, Hart, Stern, 2015, str. 1-18).

${ }^{27}$ Z vzpostavitvijo Poveljstva sil SV leta 2017 se lahko pričakuje, kot je to že bilo v preteklosti, da se bo del teh pristojnosti prenesel na poveljnika Poveljstva sil.

${ }^{28}$ Večina članov tako oblikovane operativne skupine bi v pripravljalnem času oblikovala začasno delovno skupino, ki bi pripravila podlago za delovanje sistema, spisala katalog zmogljivosti SV, proučila in posodobila ukrepe nacionalnovarnostnega sistema, ki se nanašajo na obrambno področje, pripravila predloge spremembe zakonodaje z obravnavanega področja, zapisala direktivo kriznega upravljanja ipd.
} 
stalnega predstavnika v procesu celotnega kriznega upravljanja v okviru NCKU, ne le pri zagotavljanju razmer za njegovo delovanje.

Pogosto se pozablja na navidezno stranske akterje v procesu upravljanja krize. V mednarodnem okolju se pogosto pozablja na vojaška predstavništva (VOPRE). Ta bi morala imeti znotraj procesa kriznega odločanja Nata in EU jasno določene vloge in naloge za aktivnejše sodelovanje pri kriznem upravljanju.

Na terenu je treba določiti subjekt, zadolžen za vodenje koordinacije med vsemi sodelujočimi. SV je, glede na mnenja mnogih strokovnjakov s tega področja (na primer Kotnik, 2005, Malešič, 2008, Škerbinc, 2014), edina sposobna na terenu organizirati operativni center za spremljanje situacije in koordinacijo vseh akterjev, zato bi bilo treba voditi politiko v tej smeri kot tudi v smeri povečanja vloge SV pri kriznem upravljanju, saj je po izkušnjah iz prakse vedno prepozno angažirana.

Skica 2: Predlog umestitve in prilagoditve koncepta kriznega upravljanja v SV

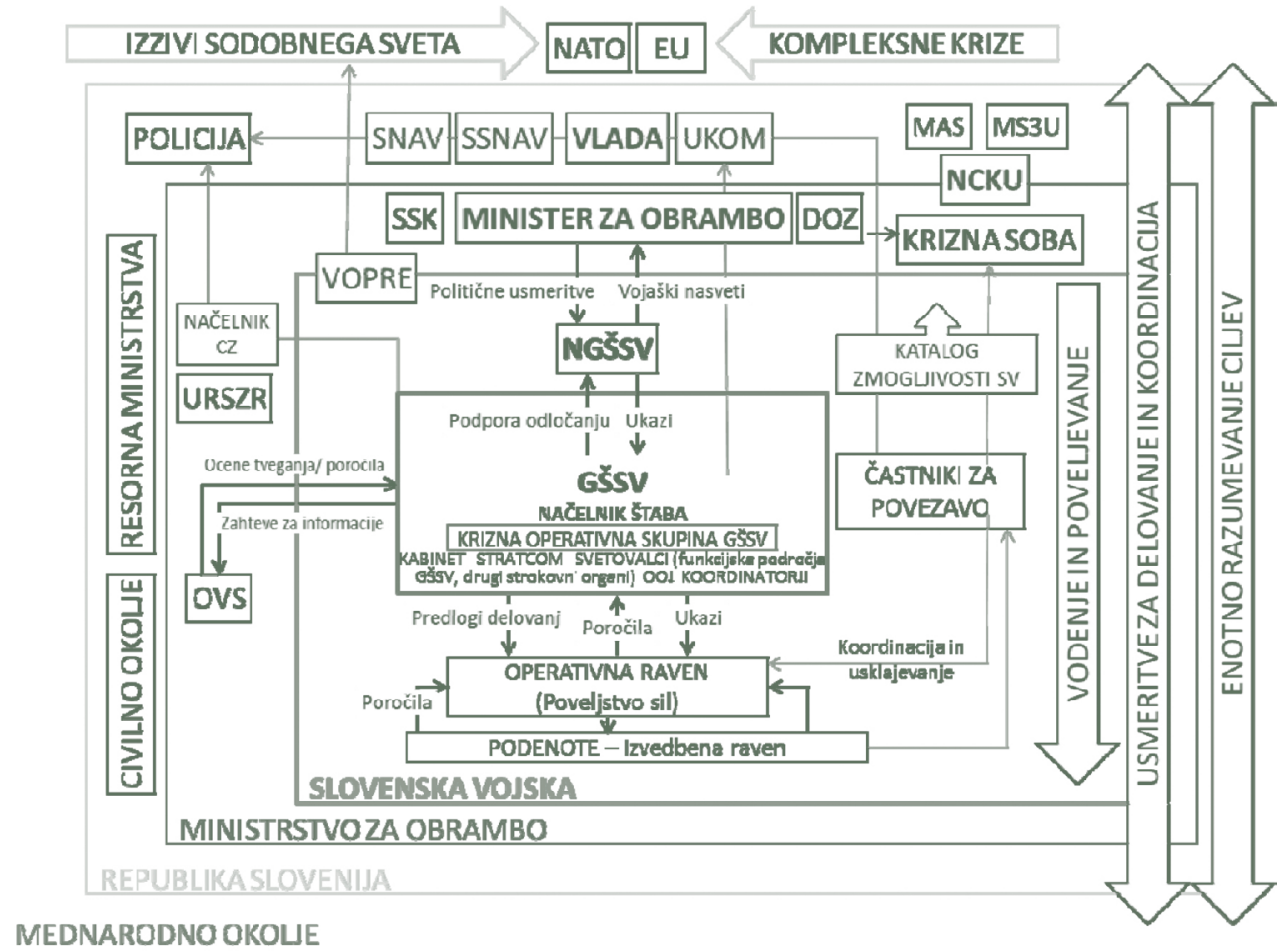

Na skici 2 je grafično predstavljen koncept kriznega upravljanja v SV. Pomembno je, da se lahko struktura povezuje z vsemi nacionalnimi in mednarodnimi elementi znotraj sistema na svoji ravni vodenja in poveljevanja, $\mathrm{v}$ okviru usmeritev in navodil 
političnih organov. Koncept kriznega upravljanja v SV bi moral biti umeščen prek načelnika GŠSV vertikalno k ministru za obrambo, saj, kot ugotavljata Vuga in Ferlin (2016), krize zahtevajo politično podporo in pretok informacij z odločevalne ravni na izvedbeno. Poleg zarisanih formalnih poti sodelovanja se na operativnotaktični ravni pričakuje intenzivno medinstitucionalno povezovanje, usklajeno prek posameznih koordinacijskih centrov do NCKU, ki poskrbi za ustrezno izvedbo oblike delovanja.

\section{Procesi}

Preden se oblikujeta oblika in način štabnega dela, je treba odpraviti nejasnosti glede razmejitev pristojnosti za odločanje na politični in vojaški ravni (kakšni sta vlogi ministrstva in SV, kdaj aktivirati zmogljivosti SV ipd.). Pri vzpostavljanju štabnih postopkov kriznega upravljanja bi bilo na strateški in operativni ravni smiselno uvesti Natov šestfazni postopek pristopa k reševanju kriz in znotraj njega umestiti nacionalne posebnosti. V sedanjem stanju, ko v SV na določenih ravneh velja petfazni proces vojaškega odločanja, nikakor ni mogoče uskladiti teh postopkov. Poleg tega je treba uskladiti tudi mehanizme kriznega odzivanja, saj je bilo ugotovljeno v analizah po vaji, da so različni in neusklajeni ter ne omogočajo pridobivanja skupne slike in usklajenega delovanja.

Postopek aktivacije SV (upoštevajoč ugotovitve avtoric Ferlin in Vuga, 2016) bi lahko začel minister za obrambo, po naročilu vlade oziroma ob aktiviranju NCKU prek stalnega člana SV. V nadaljevanju bi bilo treba oblikovati ustaljen sistem poročanja znotraj SV in navzven do vseh ravni ter pravno podlago delovanja $\mathrm{V}$ kriznih razmerah, ki bi bila hierarhično urejena in skladna s ključnimi področnimi nacionalnimi in mednarodnimi dokumenti (NCRSM, Lizbonska pogodba ipd.). Prepoznane rešitve, usklajene s procesi in postopki kriznega upravljana Nata in EU, bi bilo treba zapisati v normativni akt, ki bi imel pravnoformalno veljavo in bi ustrezal vsem predstavljenim merilom učinkovitega kriznega upravljanja.

V spopadanju s kompleksnimi krizami je ključno medresorsko in mednarodno sodelovanje. Razviti je treba povezovalne in koordinacijske mehanizme z MO in drugo nacionalno strukturo kriznega upravljanja (na primer policijo, civilno zaščito, kinologi ipd.), ki bodo usklajeni s postopki Nata in EU. Treba je paziti tudi na usklajenost organov, funkcij in postopkov kriznega upravljanja. Preglednica $1 \mathrm{v}$ nadaljevanju daje nekatera izhodišča za upoštevanje tega elementa, saj prikazuje področja odstopanja od urejenosti $\mathrm{v}$ Natu in EU ter hkrati predlaga ideje za uskladitev postopkov na različnih ravneh kriznega upravljanja, znotraj katerih deluje SV. V preglednici so v stolpcu Nato in EU zapisani organi, ki opravljajo določeno funkcijo, v stolpcih, ki opisujeta funkcijske organe RS in MO/SV, pa so zapisani tisti, ki naj bi po naši oceni v posodobljenem sistemu kriznega upravljanja izvajali neko funkcijo. 


\begin{tabular}{|c|c|c|c|c|c|}
\hline \multirow{11}{*}{$\begin{array}{r}\text { Preglednica 1: } \\
\text { Primerjava v } \\
\text { prispevku anali- } \\
\text { ziranih subjektov } \\
\text { kriznega } \\
\text { upravljanja }\end{array}$} & $\begin{array}{l}\text { Funkcije }^{1} \text { in } \\
\text { odločitve }\end{array}$ & Nato & EU & RS & $\mathrm{MO} / \mathrm{SV}$ \\
\hline & Funkcija odločanja & NAC & Svet EU & Vlada RS & Minister/NGŠSV \\
\hline & $\begin{array}{l}\text { Politično- } \\
\text { posvetovalna } \\
\text { funkcija }\end{array}$ & IS, MC, IMS & $\begin{array}{l}\text { EEAS in Oddelek } \\
\text { za krizno odzivanje } \\
\text { in operativno } \\
\text { načrtovanje }\end{array}$ & SNAV & $\begin{array}{l}\text { Kolegij ministra/ } \\
\text { politični } \\
\text { svetovalci } \\
\text { NGŠSV }\end{array}$ \\
\hline & $\begin{array}{l}\text { Funkcija } \\
\text { usklajevanja in } \\
\text { vodenja }\end{array}$ & $\begin{array}{l}\text { MC z IMS, } \\
\text { SACEUR s štabom }\end{array}$ & $\begin{array}{l}\text { Visoka } \\
\text { predstavnica EU }\end{array}$ & $\begin{array}{l}\text { Po pooblastilu } \\
\text { vlade SSNAV in } \\
\text { vodja SSNAV }\end{array}$ & $\begin{array}{l}\text { Koordinator } \\
\text { za operativno } \\
\text { skupino }\end{array}$ \\
\hline & $\begin{array}{l}\text { Funkcija } \\
\text { spremljanja } \\
\text { situacije in } \\
\text { usklajevanja }\end{array}$ & NIWS', SITCOM & Situational room & MS3U & $\begin{array}{l}\text { Operativna } \\
\text { skupina GŠSV } \\
\text { in OVS v } \\
\text { sodelovanju z J2 }\end{array}$ \\
\hline & $\begin{array}{l}\text { Funkcija analize, } \\
\text { predvidevanja in } \\
\text { načrtovanja }\end{array}$ & $\begin{array}{l}\text { NIWS in IMS, } \\
\text { Shape }\end{array}$ & EEAS, CMDP & $\begin{array}{l}\text { MAS, razširjena } \\
\text { stalna OpS }\end{array}$ & OVS \\
\hline & $\begin{array}{l}\text { Funkcija kriznega } \\
\text { komuniciranja }\end{array}$ & StratCom & $\begin{array}{l}\text { Urad visoke } \\
\text { predstavnice za } \\
\text { SZVP/SOVP }\end{array}$ & UKOM, SSNAV & $\begin{array}{l}\text { Združena SSKJ } \\
\text { OOJ v StratCom }\end{array}$ \\
\hline & $\begin{array}{l}\text { Funkcija pokrizne } \\
\text { analize }\end{array}$ & IS, MC, IMS & EEAS, CMDP & SSNAV & $\begin{array}{l}\text { Operativna } \\
\text { skupina GŠSV }\end{array}$ \\
\hline & Podporne funkcije & $\begin{array}{l}\text { Države članice, } \\
\text { civilni strokovnjaki }\end{array}$ & $\begin{array}{l}\text { Države članice, } \\
\text { funkcijski } \\
\text { strokovnjaki }\end{array}$ & $\begin{array}{l}\text { NCKU, posamezni } \\
\text { resorni elementi }\end{array}$ & Strokovne službe \\
\hline & $\begin{array}{l}\text { Prvi izdani } \\
\text { (opozorilni) } \\
\text { dokument }\end{array}$ & $\begin{array}{l}\text { IS - začetne } \\
\text { usmeritve }\end{array}$ & $\begin{array}{l}\text { Nasveti za } \\
\text { delovanje }\end{array}$ & $\begin{array}{l}\text { Sprejetje kriznih } \\
\text { ukrepov }\end{array}$ & $\begin{array}{l}\text { Ukaz za } \\
\text { delovanje }\end{array}$ \\
\hline & Izvedbeni organ & $\begin{array}{l}\text { Države članice s } \\
\text { svojimi OS }\end{array}$ & $\begin{array}{l}\text { Civilni strokovnjaki, } \\
\text { države članice, } \\
\text { evropske sile }\end{array}$ & $\begin{array}{l}\text { CZ, Policija, SV, } \\
\text { druge ustanove } \\
\text { NVS }\end{array}$ & CZ/SV \\
\hline
\end{tabular}

Iz preglednice je razvidno, da bi bilo treba poiskati primerljive entitete v SV, nacionalnem okolju in znotraj EU ter Nata. Tako bodo določeni nosilci posamezne faze procesa in ne bo prevelikega odstopanja na ravneh odločanja ter sledenja korakom procesa kriznega upravljanja. Prav tako bo jasneje, kateri organ je funkcijsko zavezan drugemu na višji ravni. Če za ilustracijo vzamemo NAC, kot najvišji politični organ Nata, lahko ugotovimo, da mu je na nacionalni ravni primerljivo

\footnotetext{
29 Za lažjo primerjavo so funkcije povzete po Vuga, Ferlin, 2016.

${ }^{30}$ Razlaga še nepredstavljenih kratic po zapisanem vrstnem redu v preglednici: NIWS - Natov obveščevalnoopozorilni sistem (Nato Intelligence Warning System), OVS - Obveščevalnovarnostna služba MO, $J 2$ - obveščevalna celica SV, OpS - Operativna skupina, SSK/OOJ - Služba za strateško komuniciranje MO/ Oddelek za odnose z javnostmi GŠSV, IS - Mednarodni štab (International Staff), CMDP - Direktorat za krizno upravljanje in načrtovanje (Crisis Management and Plans Directorate), OS - oborožene sile.
} 
MO (IS je primerljiv s kolegijem ministra za obrambo). Podobno je tudi z MC, ki je najvišji vojaški organ Nata, v RS mu je primerljiv GŠSV (IMS je primerljiv s štabom GŠSV). Na operativni ravni v Natu delujeta SACEUR in $S_{A C T}{ }^{31}, v$ SV pa je najvišji operativni organ poveljevanja Poveljstvo sil, ki se leta 2017 ponovno vzpostavlja.

Poleg vseh omenjenih novosti in izboljšav se ne sme pozabiti pozitivna praksa, ugotovljena na vajah in v resničnih situacijah delovanja v krizah. Njihove prednosti bi bilo treba primerno izkoriščati, zlasti pri posodabljanju konceptov in procesov $\mathrm{s}$ področja kriznega upravljanja (na primer prednosti krizne sobe, uporabnost častnikov za povezavo, skupnega portala, širjenje komuniciranja na nižjih ravneh, zavedanje kibernetske nevarnosti, iniciativnost in spremljanje situacije preden začne delovati vojska, zbiranje odzivov na terenu, skrb za zaščito svojih sil ipd.).

Sklep Pregled sistemov kriznega upravljanja v Natu in EU ter na nacionalni ravni, analize zakonodaje, vaj kriznega upravljanja ter delovanja v dveh realnih krizah potrjujejo izhodiščni trditvi iz uvoda. Z gotovostjo lahko sklepamo, da umestitev SV v sistem kriznega upravljanja na obrambnem področju ni celovita in da to posledično zmanjšuje njeno vlogo ter učinek pri delovanju in uresničevanju ciljev kriznega upravljanja pri odzivanju na krize. Ta spoznanja vodijo do sklepa, da morata posodobitev in izoblikovanje učinkovitega sistema kriznega upravljanja v SV slediti celovitim rešitvam in razvojni dinamiki tega področja na nacionalni ravni, vendar je treba nujno hkrati s tem tudi izoblikovati vojaško strokovno omizje, ki bo sposobno o teh sodobnih družbenih vprašanjih razpravljati ter, kar je še pomembnejše, posodobiti sistem, ki bo sposoben v vseh kriznih okoliščinah sodelovati pri upravljanju sodobnih in kompleksnih kriz.

Prispevek ne izpostavlja, da SV ni uspešna pri odzivanju na krize, saj ima tako zmogljivosti kot tudi znanje in izkušnje za intenzivnejše delovanje v kriznih razmerah. Kar dodatno vzbuja skrb in polemiko, je povezano s prestižno miselnostjo ključnih odločevalcev v kriznih razmerah, kar se posledično pogosto kaže v prepozni aktiviranosti SV oziroma v premajhnem obsegu. Njen uspeh je ravno zato velikokrat odvisen od nesistemskih rešitev, kot so motiviranost, samoiniciativnost, ad hoc usklajevanja in delovanja, ki pa ne omogočajo dolgoročnega delovanja $\mathrm{v}$ krizi, puščajo za seboj preveč odprtih vprašanj, izčrpavajo sistem in ne predlagajo celovitega pristopa. Ugotovitve nakazujejo, da bi bilo treba pri dopolnitvi oziroma oblikovanju sistema kriznega upravljanja v SV nameniti več pozornosti področju dopolnjevanja in kadrovskim rešitvam, sistemu vodenja in poveljevanja, razmejitvi odgovornosti in pristojnosti (predvsem na strateški in operativni ravni) ter usklajenemu delovanju, ki je ključno v tem procesu. Povečati bi bilo treba transparentnost in poskrbeti za boljšo obveščenost prebivalstva glede postopkov ravnanja ob večjih krizah in glede delovanja države. Nujno je oblikovati enoten sistem komuniciranja, ki bi temeljil na enotni strategiji komuniciranja ob kompleksnih krizah in ki bi bil sestavni del

\footnotetext{
${ }^{31}$ Primerljivost strukturiranosti Nata je treba obravnavati zgolj ilustrativno, saj je večnacionalne strukture težko neposredno primerjati z nacionalnimi.
} 
upravljanja informacij ter skladen z načeli Natovega »StratComa«. Treba je prenoviti in na novo določiti ukrepe kriznega odzivanja ter pripraviti enotno metodologijo za pokrizno analizo. Izoblikovati je treba mehanizme, ki bodo omogočili celovito ocenjevanje ogroženosti in identifikacijo področnih in kompleksnih kriz ter pripraviti manjkajoče načrte za odzivanje nanje. Aktivnosti za posodobitev in oblikovanje celovitega sistema kriznega upravljanja v SV bi bilo treba tudi časovno prilagoditi aktivnostim že potekajočega oblikovanja in uvajanja prenovljenega nacionalnega sistema KUV.

Raziskovalna spoznanja, strnjena s sintezo vseh teoretičnih in aplikativnih ugotovitev, izrazito poudarjajo nujnost in potrebo SV po posodobljenem ter celovitem sistemu kriznega upravljanja z jasno določenimi nalogami, ki bo v vseh fazah in segmentih delovanja usklajen z nacionalnim in Natovim kriznim upravljanjem ter kriznim upravljanjem EU. Predlagana ideja koncepta kriznega upravljanja SV daje v tem kontekstu celovit sistematični in shematski prikaz ureditve in umestitve področja kriznega upravljanja v SV, ki lahko kot dodatna strokovna podlaga koristi SV in MO pri iskanju učinkovitih rešitev na področju kriznega upravljanja.

Pri vsem tem se moramo zavedati, da se morajo pri posodabljanju področja kriznega upravljanja v SV upoštevati tudi sodobni varnostni izzivi, nova ogrožanja, kompleksnost situacij in razsežnost posledic. Krizo je namreč veliko bolje pričakati $\mathrm{v}$ pripravljenosti, kot da nas ujame nepripravljene.

\section{Literatura}

1. Analiza delovanja SV v podporo Policiji v zvezi z migrantsko problematiko za obdobje oktober 2015 do maj 2016. MO RS, 225-1/2016-959, 30. 6. 2016.

2. Blagonič, A., 2014. Usposabljanje za potrebe civilne obrambe, civilno kriznega upravljanja v okviru obrambnega sistema republike Slovenije. Fakulteta za državne in evropske študije, magistrska naloga.

3. Boin, Arjen, Hart, T., Paul, Stern, E., 2006. The Politics of Crisis Management: Public Leadership under Pressure, Cambridge University Press, Cambridge, United Kingdom.

4. Celovita analiza vodstvene obrambno zaščitne vaje v Ministrstvu za obrambo (POMLAD 2011). MO RS, 802-20/2011-94, 19. 5. 2011.

5. Crisis Management and Planning Directorate (CMPD), 2016. http://eeas.europa.eu/csdp/ structures-instruments-agencies/cmpd/index_en.htm (4. 8. 2016).

6. Crisis management. http://www.nato.int/cps/en/natolive/topics_49192.htm (20. 7. 2016).

7. Ekengren, M.; Groenleer, M., 2006. European Union crisis management: challenges for research and practice. International Journal of Emergency Management, vol. 3, Issue 1, str. 83-90.

8. EU External Action, Crisis response. 2016, http://eeas.europa.eu/crisis-response/index_ en.htm (3. 8. 2016).

9. Furlan, Branimir (in drugi), 2006. Vojaška doktrina, MO RS.

10. Kotnik-Dvojmoč, I., 2008. Oblikovanje sodobnega sistema kriznega upravljanja v Republiki Sloveniji s preoblikovanjem in nadgradnjo dosedanjih rešitev. Ujma: revija za vprašanja varstva pred naravnimi in drugimi nesrečami, št. 22 (2008), 209-218.

11. Malešič, M., (ur.), 2006: Komuniciranje v krizi. FDV, Ljubljana.

12. Malešič, M., 2008. Odzivanje na kompleksno varnostno krizo v Sloveniji: norma, struktura in funkcija. Teorija in praksa, let. 45 1/2, 113-127. 
13. Načrt vaj v obrambnem sistemu in sistemu varstva pred naravnimi in drugimi nesrečami $v$ letu 2016, Vlada RS.

14. Oddelek za obrambno krizno načrtovanje, 2016. http://intra.mors.si/index.php?id=2843 (25. 7. 2016).

15. Odlok o Svetu za nacionalno varnost (Odlok SNAV). Uradni list RS 70/2013.

16. Poročilo o Natovi vaji kriznega upravljanja CMX 11 v Republiki Sloveniji. Vlada RS, 87100-14/2014/8, 23. 12. 2014.

17. Poročilo o sodelovanju RS na Natovi vaji kriznega upravljanja CMX 12. MO RS, 8012/2012-47, 1. 2. 2013.

18. Poročilo o sodelovanju RS na vaji kriznega upravljanja CME12. MO RS, 801-1/2012-63, 18. 1. 2013.

19. Poročilo o sodelovanju RS na vaji kriznega upravljanja CME14. Vlada RS, 8710014/2014/8, 23. 12. 2014.

20. Poročilo o vaji CMX15 na Ministrstvu za obrambo (CMX15). MO RS, 801-2/2015-43, 30. 4. 2015.

21. Poročilo o vaji CME 11. Vlada RS, 87100-1/2011/27, 5. 4. 2012.

22. Predlog Zakon o obrambi, EVA 2016-1911-0001, 13. 4. 2016.

23. Prezelj, I., 2005. Nacionalni sistemi kriznega menedžmenta. FDV, Ljubljana.

24. Prezelj, Iztok, 2005. Tipične težave pri kriznem upravljanju. Ujma: revija za vprašanja varstva pred naravnimi in drugimi nesrečami, št. 19 (2005), 190-195.

25. Raduha, Nina, 2016. Krizno upravljanje na obrambnem področju s poudarkom v Slovenski vojski, zaključna naloga višjega štabnega tečaja.

26. Raduha, Nina, 2016. Natov koncept strateških komunikacij v RS s poudarkom na SV. Sodobni vojaški izzivi. December $2016-18 /$ št. 4.

27. Resolucija o strategiji nacionalne varnosti Republike Slovenije (ReSNV-1). Uradni list RS: $27 / 2010$.

28. Sklep Vlade Republike Slovenije, št. 810-02/2002-2 z dne 16. 1. 2003.

29. Strateški pregled obrambe, 2016. Ministrstvo za obrambo, Ljubljana.

30. Uredba o obrambnem načrtovanju,Uradni list RS, št. 51/13.

31. Uredba o organizaciji in delovanju Nacionalnega centra za krizno upravljanje. Uradni list RS, št. 9/06.

32. URSZR, 2014. Poročilo o posledicah poplav, visokega snega in žleda v Republiki Sloveniji med 30. januarjem in 9. februarjem. Slovenija v ledenih okovih-2014, izzivi in odzivi, zbornik, (ur. Malešič, Svete), FDV, 13-50.

33. Vlada RS, 2016. Posodobljen sistem kriznega upravljanja in vodenja. http://www.vlada. si/teme_in_projekti/projektna_pisarna/posodobljen_sistem_kriznega_upravljanja_in_ vodenja/ (29. 7. 2016).

34. Vuga-Beršnjak, Janja, Ferlin, Anica, 2016. Krizno upravljanje in vodenje v Republiki Sloveniji: predlog strukture KUV pri vladi RS. MO RS, Ljubljana.

35. Zaključno poročilo o vaji CMX 16. MO RS, 801-3/2015-117, 1. 4. 2016.

36. Zakon o obrambi (ZObr-UPB1). Uradni list RS, št. 103/2004-uradno prečiščeno besedilo. 